into the microalbuminuria range before it induces a rise in blood pressure.

Insulin dependent diabetic patients who developed persistent or intermittent microalbuminuria were significantly more likely to have retinal lesions at baseline than those who remained normoalbuminuric. This difference was maintained at follow up and has also been shown by other workers. ${ }^{24}$

In conclusion our study shows that raised albumin excretion rate and blood pressure are concomitant phenomena in insulin dependent diabetic patients progressing to microalbuminuria. A background of poor blood glucose control compounded with a rise in blood pressure and, to a lesser extent, a history of smoking are crucial determinants of this process.

Members of the study group were Colin F Close, Andrea Collins, Angela Goodwin, Caron Hill, R John Jarrett, Sharon L Jones, Harry Keen, Graham S Scott, GianCarlo Viberti, Hita Vora, and Jeannie Yip, Guy's Hospital, London; Anna Grenfell, Michael J Sampson, and Peter J Watkins, King's College Hospital, London; Carol Fishwick, Wendy Gatling and Ronald D Hill, Poole General Hospital; and Sally M Marshall, University of Newcastle upon Tyne.

This work was supported by a grant from the Department of Health and by Guy's Hospital Special Trustees. We thank the following colleagues for allowing us to study their patients: Dr N Essex, Mayday University Hospital, Croydon; Dr G Jackson, Lewisham Hospital, London; Dr C Lowry and Professor P Sonksen, St Thomas's Hospital, London; Dr P Marsden, Greenwich District Hospital, London; Dr P Stephenson, Queen Elizabeth Hospital, Gateshead; Dr E T Young, Ashington General Hospital; and Dr J Yudkin, Whittington Hospital, London.

1 Viberti GC, Hill RD, Jarrett RJ, Argyropoulos A, Mahmud U, Keen H. Microalbuminuria as a predictor of clinical nephropathy in insulindependent diabetes mellitus. Lancet 1982;i:1430-2.

2 Mathiesen ER, Øxenboll B, Johansen K, Svendsen PA, Deckert T. Incipient nephropathy in type 1 (insulin-dependent) diabetes. Diabetologia 1984;26: 406-10.

3 Parving HH, Øxenboll B, Svendsen PA, Christiansen JS, Andersen AR. Early detection of patients at risk of developing diabetic nephropathy: a longitudinal study of urinary albumin excretion. Acta Endocrinol 1982;100:500-5.

4 Mogensen CE, Christensen CK. Predicting diabetic nephropathy in insulindependent patients. N Engl $\mathcal{G}$ Med 1984;311:89-93.
5 Wiseman MJ, Viberti GC, Mackintosh D, Jarrett RJ, Keen H. Glycaemia, arterial pressure and microalbuminuria in type 1 (insulin-dependent) diabetes mellitus. Diabetologia 1984;26:402-5.

6 Feldt-Rasmussen B, Mathiesen ER, Deckert T. Effect of two years of strict metabolic control on progression of incipient nephropathy in insulindependent diabetes. Lancet 1986;ii:1300-4.

7 Microalbuminuria Collaborative Study Group, UK. Microalbuminuria in type 1 (insulin-dependent) diabetic patients: prevalence and clinical characteristics. Diabetes Care 1992;4:495-501.

8 Messent JWC, Elliott TG, Hill RD, Jarrett RJ, Keen H, Viberti GC. Prognostic significance of microalbuminuria in insulin-dependent diabetes mellitus-a 23 year follow-up study. Kidney Int 1992;41:836-9.

9 Feldt-Rasmussen B, Mathiesen ER, Jensen T, Lauritzen T, Deckert T. Effect of improved metabolic control on loss of kidney function in type 1 (insulindependent) diabetic patients: an update of the Steno studies. Diabetologia dependent) diabetic

10 Chavers BM, Bilous RW, Ellis EN, Steffes MW, Mauer SM. Glomerular lesions and urinary albumin excretion in type 1 diabetes without overt proteinuria. N Engl f Med 1989;320:966-70.

11 Gatling W, Knight C, Hill RD. Screening for early diabetic nephropathy: which sample to detect microalbuminuria? Diabetic Med 1985;2:451-5.

12 Mathiesen ER, Renn B, Jensen T, Storm B, Deckert T. The relationship between blood pressure and urinary albumin excretion in the developmen of microalbuminuria. Diabetes 1990;39:245-9.

13 Mogensen CE, Chachati A, Close CF, Deckert T, Honnel E, et al. Microalbuminuria: an early marker of renal involvement in diabetes. Uraemia Invest 1986;9:85-95.

14 World Health Organisation Multinational Study of Vascular Disease in Diabetes. Prevalence of small vessel and large vessel disease in diabetic patients from 14 centres. Diabetologia 1985;28:615-40.

15 Jarrett RJ, Keen H, Grabauskas V. The WHO multinational study of vascular disease in diabetes: general description. Diabetes Care 1979;2:175-86.

16 SAS users' guide: statistics: version 5. Cary, North Carolina: SAS Institute, 1985.

17 Armitage P, Berry G. Statistical methods in medical research. 2nd ed. Oxford: Blackwells, 1987:408-14

18 Krolewski AS, Warram JH, Christlieb AR, Busick EJ, Khan CR. The changing natural history of neophropathy in type 1 diabetes. $\mathrm{Am} \mathrm{f}$ Med 1985;78:785-94

19 Andersen AR, Christiansen JS, Andersen JK, Kreiner S, Deckert T. Diabetic nephropathy in type 1 (insulin-dependent) diabetes: an epidemiological study Diabetologia 1983;25:496-501.

20 Chase HP, Garg SK, Marshall G, Begg CL, Harris F, Jackson WE, et al. Cigarette smoking increases the risk of albuminuria among subjects with type 1 diabetes. JAMA 1991;265:614-7.

21 The Kroc Collaborative Study Group. Blood glucose control and evoluation of diabetic retinopathy and albuminuria. $N$ Engl f Med 1984;6:2365-9.

22 Reid DD, Hamilton PJS, McCartney P, Rose G, Jarrett RJ, Keen H. Smoking and other risk factors for coronary heart disease in British civil servants. Lancet 1976;ii:979-84.

23 Rudberg S, Persson B, Dahlquist G. Increased glomerular filtration rate as a predictor of diabetic nephropathy -an 8-year prospective study. Kidney In 1992;41:822-8.

24 Vigstrup J, Mogensen CE. Prolifrative diabetic retinopathy: at risk patients identified by early detection of microalbuminuria. Acta Ophthalmol 1985;63: $530-43$

(Accepted 2 March 1993)
University of Sheffield

Department of Paediatrics,

Section of Paediatric

Haematology, Children's

Hospital, Sheffield

S102TH

Helena Davies, Leukaemia

Research Fund clinical fellow

John Lilleyman, head of

section

University of Sheffield

Department of Medicine,

Section of Pharmacology

and Therapeutics, Royal

Hallamshire Hospital,

Sheffield S10 2JF

Lynne Lennard, research

scientist

Correspondence to:

Dr Lilleyman.

BMF 1993;306:1239-40

\section{Variable mercaptopurine metabolism in children with leukaemia: a problem of non-compliance?}

\author{
Helena A Davies, Lynne Lennard, \\ John S Lilleyman
}

The successful treatment of childhood lymphoblastic leukaemia depends in part on extended oral medication with mercaptopurine. The most important group of metabolites of mercaptopurine, 6-thioguanine nucleotides, accumulate slowly in red cells to reach a steady state concentration in nearly all children after one to four weeks.' The concentration of these metabolites correlates with cytotoxicity and can be used to assess the adequacy of treatment in a way broadly analogous to the measurement of glycated haemoglobin in the control of diabetes.

Some interpatient variability in the concentration of 6-thioguanine nucleotides is undoubtedly due to differences in the way patients metabolise mercaptopurine, ${ }^{2}$ but we have seen intrapatient variability that needs an alternative explanation. Scant consideration has been given to the question of compliance, ${ }^{34}$ so we undertook a preliminary study to see if children with acute lymphoblastic leukaemia always take their mercaptopurine tablets.

\section{Patients, methods, and results}

We recruited 35 consecutive children with acute lymphoblastic leukaemia who were treated in Sheffield or Nottingham, were in their first remission, and had been receiving similar maintenance chemotherapy that included continuous treatment with mercaptopurine at a standard daily dose of $75 \mathrm{mg} / \mathrm{m}^{2}$ for at least nine months. The children were seen at least fortnightly, and their drug doses were reduced if they developed neutropenia or thrombocytopenia. On the basis of whether they had ever taken the standard dose of mercaptopurine for four or more weeks continuously without developing cytopenias, we designated 22 of the children as tolerant of the treatment and 13 as nontolerant.

After the tolerant children had completed at least four weeks of treatment with the standard dose of mercaptopurine (when the concentration of 6thioguanine nucleotides in red cells should have been reaching a steady value) we took blood samples to measure the concentration of these metabolites. The blood was taken at the time of routine venepuncture, and the methods of measuring the metabolites have been described elsewhere. ${ }^{5}$ We also assessed the compliance of all 35 children with their treatment by means of a structured interview. 
The table shows the highest and lowest concentrations of 6-thioguanine nucleotides recorded for each child who was tolerant of mercaptopurine and the ratios of these concentrations. The ratios for six children were 1.9 or more, indicating wide fluctuations in the metabolite concentrations. At the time of their lowest recorded concentration they had been taking a full dose of mercaptopurine for between five and 43 weeks.

Highest and lowest concentrations of 6-thioguanine nucleotides in red cells of 22 children with acute lymphoblastic leukaemia who had been taking mercaptopurine $75 \mathrm{mg} / \mathrm{m}^{2}$ for at least four weeks

\begin{tabular}{|c|c|c|c|}
\hline \multirow[b]{2}{*}{ Case No } & \multicolumn{2}{|c|}{ Concentration ( $\mathrm{pmol} / 8 \times 10^{8}$ red cells) } & \multirow[b]{2}{*}{ Highest:Lowest } \\
\hline & Highest & Lowest & \\
\hline 1 & 443 & 413 & 1.07 \\
\hline 2 & 275 & 246 & $1 \cdot 12$ \\
\hline 3 & 491 & 425 & $1 \cdot 16$ \\
\hline 4 & $\cdot 305$ & 234 & 1.30 \\
\hline 5 & 246 & 186 & 1.32 \\
\hline 6 & 622 & 461 & 1.35 \\
\hline 7 & 269 & 198 & 1.36 \\
\hline 8 & 377 & 263 & 1.43 \\
\hline 9 & 251 & 174 & 1.44 \\
\hline 10 & 287 & 198 & 1.45 \\
\hline 11 & 246 & 168 & 1.46 \\
\hline 12 & 497 & 323 & 1.54 \\
\hline 13 & 443 & 281 & 1.58 \\
\hline 14 & 425 & 269 & 1.58 \\
\hline 15 & 485 & 305 & 1.59 \\
\hline 16 & 605 & 353 & 1.71 \\
\hline 17 & 264 & 138 & 1.91 \\
\hline 18 & 690 & 354 & 1.95 \\
\hline 19 & 330 & 144 & $2 \cdot 29$ \\
\hline 20 & 228 & 90 & 2.53 \\
\hline 21 & 294 & 108 & $2 \cdot 72$ \\
\hline 22 & 282 & 96 & 2.94 \\
\hline $\begin{array}{l}\text { Median value } \\
\text { (range) }\end{array}$ & $\begin{array}{c}318 \\
(228-690)\end{array}$ & $\begin{array}{c}240 \\
(90-461)\end{array}$ & \\
\hline
\end{tabular}

Two children (cases 21 and 22) admitted failing to take their tablets. Both were adolescent girls in charge of their own treatment. Six others gave equivocal histories of compliance. They were all tolerant of mercaptopurine, and three had ratios of highest to lowest metabolite concentrations of 1.9 or more.

\section{Comment}

Of the 22 children supposedly taking a constant dose of mercaptopurine over a long period, six showed wide fluctuations in the concentrations of the drug's metabolites. Two of these children admitted to not taking their medication, and partial non-compliance was probable in at least three others. None of the children had no detectable metabolites, indicating that none had completely abstained from treatment. We have, however, recently received samples that had no detectable metabolites. These came from four patients from other British centres as part of a nationwide study.

Our results suggest that some one in five children with acute lymphoblastic leukaemia fail to comply fully with oral chemotherapy. If this is correct it may explain unexpected late relapses in patients with an otherwise good outlook. Recognising non-compliance is not the same as solving it. Simply escalating the dose of mercaptopurine for apparently tolerant patients who are not taking the drug is potentially dangerous if they start to comply. Serial assay of metabolites can be used to monitor suspected offenders, but continual vigilance and education in the clinic are also needed.

This work was supported by the Leukaemia Research Fund of Great Britain and the Yorkshire Cancer Research Campaign. We thank Dr Peter Barbor and Dr David Walker, University Hospital, Nottingham, for allowing us to study their patients.

1 Lennard L, Lilleyman JS. Variable mercaptopurine metabolism and treatment outcome in childhood lymphoblastic leukaemia. J Clin Oncol 1989;7:816-23. 2 Lennard L, Lilleyman JS, Van Loon J, Weinshilboum RM. Genetic variation in response to 6-mercaptopurine for childhood lymphoblastic leukaemia. Lancet 1990;336:225-9.

3 Smith SD, Rosen D, Trueworthy RC, Lowman JT. A reliable method for evaluating drug compliance in children with cancer. Cancer 1979;43:169-73.

4 Tebbi CK, Cummings KM, Zevon MA, Smith L Richards M, Mallon J. Compliance of pediatric and adolescent cancer patients. Cancer 1986:58: 1179-84.

5 Lennard L, Singleton $\mathrm{H}$. High performance liquid chromatographic assay of the methyl and nucleotide metabolites of 6-mercaptopurine: quantitation of the methyl and nucleotide metabolites of 6-mercaptopurine: quantitation of
red blood cell 6-thioguanine nucleotide, 6-thioinosinic acid and 6-methylmercaptopurine metabolites in a single sample. 9 Chromatogr 1992;583:83-90.

(Accepted 4 March 1993)

\section{MEMORABLE PATIENTS}

\section{Hearing the angels' wings}

During the second world war practice in London was stressful. I recall being telephoned about eleven o'clock one night by a patient who I remembered was a naval captain. Speaking with obvious authority he asked me to see a patient. "When?" I asked. "Now," he said, "and send the bill to room 121 at the Admiralty." It was a quiet night with no air raids and soon an olive green Hillman appeared from which emerged a tall, upstanding figure in combat dress with no insignia or shoulder flashes of any sort. I dealt with his acute toothache by simple tooth pulp decompression so within half an hour he was back in the car and vanished into the mist. I ruefully compared my tensed up weariness with his air of calm and ease, and this continued to bother me even after I read of a naval raid in Norway with prisoners taken and installations blown up. The ships had got away safely.

Three years later I spotted the captain at a party. I asked him, "Do you remember that chap you sent me in the middle of the night?" When he nodded affirmatively I realised that I had known all along the answer to the question I then foolishly asked. "He didn't come back, did he?" "No," he replied, "They waited for him as long as they could."

Thirty years later the exact spot of the landing was pointed out to me. It was now a neat and tidy little place with small houses glinting in the sun. By then I was oldish myself and I realised that at the end of life we prefer to be at home. Probably that nice young man felt the same.

I also recall a patient who visited me regularly until for reasons of health she asked for a domiciliary visit. These became more frequent, ending up in little more than inspections and conversation. With further decline in health she moved into a ground floor flat overlooking a pleasant Chelsea square with a nurse discreetly in the background. After one visit she took my hand and turned her cheek up to be kissed, which I did as gracefully as I could. It was a sunny bright March day with blue sky and scudding clouds. The trees in the square were still black without sign of leaf and I knew at that moment that she would never see them any other way. She died soon afterwards.

Doctors see patients who are ill, sometimes terminally ill. Dentists see patients who by and large are well, but in the rush and tumble of daily affairs we take these incidents as part of the day's work. It is only in retrospect we realise that if we had thought about it at the time we could have been hearing the beating of the angels' wings.- ROBERT CUTLER is a retired general dental practitioner in Surbiton, Surrey

We welcome contributions to fillers: $A$ patient who changed $m y$ practice; $A$ paper that changed my practice; $A$ memorable patient The message I would most like to leave behind, or similar topics. 